
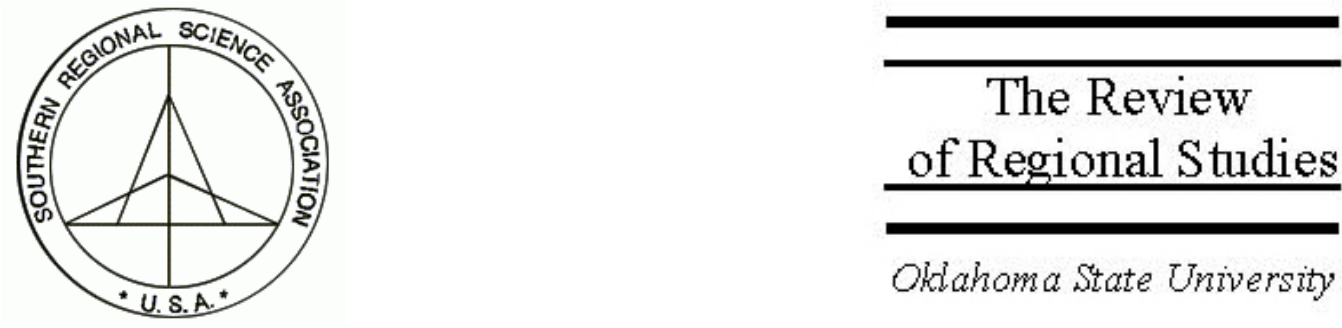

\title{
Right-to-Work Legislation, Social Capital, and Variations in State Union Density
}

\author{
Raymond Hogler \\ Professor of Management, Colorado State University, Ft. Collins, CO 80523 \\ email: Raymond.Hogler@colostate.edu \\ Steven Shulman \\ Professor of Economics, Colorado State University, Ft. Collins, CO 80523 \\ email: Steven.Shulmanr@colostate.edu \\ Stephan Weiler \\ Assistant Vice President and Economist, Center for the Study of Rural America, \\ Federal Reserve Bank, Kansas City, MO 64198 \\ email: Stephan.Weiler@kc.frb.org
}

\begin{abstract}
This paper exploits the variation in union membership among states to analyze the impact of rightto-work (RTW) laws on union density. The study is unique in its use of controls for employer opposition to unions, political affiliation, and social capital. These variables capture different dimensions of attitudes toward unions that can underlie both union density and the passage of RTW laws. We pay particular attention to social capital, which has not previously been used in an empirical study of union density. Our model explains over three-quarters of the state-to-state variation in union density. RTW legislation lowers union density by 8.8 percentage points, ceteris paribus. We conclude that RTW laws have a strong, negative effect on union density that is independent of underlying attitudes toward unions.
\end{abstract}

Keywords: Unions; Social capital; Right-to-work laws

JEL classification: J51; J53

We thank Dan Rickman, Ron Moomaw and Mark Partridge for their helpful comments. Send correspondence to Steven.Shulman@colostate.edu. 


\section{INTRODUCTION}

The National Labor Relations Act (NLRA) stipulates that American workers have a federally protected right to join and form unions and to engage in collective bargaining activities. Labor unions have a right to negotiate for security provisions in contracts that require all individuals covered by the agreement to support the union through payment of dues. Section 14(b) of the NLRA, however, authorizes states to prohibit those contractual arrangements, and 22 states now have such "right-to-work" (RTW) laws in effect. Most recently, the state of Oklahoma adopted RTW legislation in 2001, and a national RTW bill was introduced into the U.S. Congress in early 2003. The policy aspects of RTW legislation remain controversial, with proponents and opponents offering both economic and normative arguments to justify their positions (e.g., Greer and Baird 2003; Hogler and LaJeunesse 2002, 2003).

A substantial body of academic literature examines the economic impacts of RTW legislation, particularly its effects on economic development (see Moore 1998). This inquiry proceeds from the assumption that RTW laws signal a "pro-business environment" characterized by conditions unfavorable to union organization. Lower union density means lower wages and greater employment growth in highly unionized industries such as manufacturing. Econometric analyses confirm that RTW is negatively associated with union penetration and positively associated with employment growth in manufacturing (e.g., Holmes 1998; Dinlersoz and Hernández-Murillo 2002). However, these studies have not resolved the problems of causality. The passage of RTW laws and low union density may both be a result of anti-union attitudes, so that the correlation between RTW laws and union density would not necessarily indicate that the former is an independent cause of the latter. As Dinlersoz and Hernández-Murillo observe: "In summary, while we are tempted to associate the growth patterns and the decline in unionization with the passage of the law, we cannot rule out the possibility that the RTW law was a result of growing anti-unionism . . . and may not have been the cause of growth, per se" (2002, p. 40).

In this paper we provide new evidence about the impact of RTW laws on union density by including a set of unique controls for underlying attitudes about unionization. By examining the impact of RTW laws on union density net of the impact of employer opposition to unions, social capital, and political beliefs, we are able to evaluate the claim that the presence of RTW laws and low union density are simultaneously determined by an anti-union ideology. To anticipate, we reject this claim. Even after controlling for the social, political, and labor relations contexts for unionization, RTW laws are significantly related to lower union density. States with such legislation exhibit lower union density by 8.8 percentage points, ceteris paribus. Furthermore, the control variables also provide insights into the reasons why union density varies so markedly among states. We pay special attention to the novel social capital variable to better understand the complicated ways in which social beliefs and actions can affect union density. 


\section{A MODEL OF STATE UNION DENSITY}

Union membership varies substantially among the states. For example, unionization rates in 2003 ranged from a low of 3.1 percent of the work force in North Carolina to a peak of 24.6 percent in New York (see Table 2 for data sources). Such differences raise important questions about the nature of the U.S. labor relations system. Most significantly, given the presence of comprehensive legislation that imposes nationally uniform rules of union organizing, what causes these cross-sectional variations in union density?

The variation in union density among states can provide insight into the determinants of unionism that national or comparative studies (e.g., Lipset and Katchanovski 2001; Rose and Chaison 2001) may be unable to discern. This is particularly true of RTW laws since such laws are established by state governments. Other factors that can affect union density, such as political beliefs and employer opposition to unions, show greater and more meaningful geographic variation than changes over time. We therefore use states as the units of analysis in a cross-sectional model with union density as the dependent variable. Independent variables are described below.

\subsection{Right-to-Work Laws}

One of the central issues in the debate about state legislation and union membership is the role of RTW laws. The question is whether the legislative context for union organizing affects membership outcomes, or whether both density and the legal environment reflect underlying tastes for and beliefs about unions. This question is of more than academic interest. If RTW laws exert no independent effect on union density, then the labor movement wastes its financial and political resources when it opposes them. However, if RTW laws depress union membership rates, then organized labor acts rationally when it engages in political campaigns against RTW proposals, as it unsuccessfully did in the 2001 initiative in Oklahoma. RTW laws cannot explain the long-term decline in union density because the number of states with RTW laws has not changed enough to account for it, but RTW laws can help explain the variations in union density among states. To the extent that our findings support this assertion, they address a matter of understandable interest to the labor movement.

RTW legislation tended to emerge in the south and the west, where unions have less political and economic influence (Gall 1996); it appears both to reflect union weakness and in turn to contribute to it. Figure 1 shows the state-to-state variation in both union density and the presence of RTW laws; simple inspection suggests that RTW laws are correlated with relatively low levels of union density. For this reason, unions have long insisted that RTW legislation hampers their ability to organize workers. In response, proponents of such legislation argue that the correlation between low union density and RTW is spurious because both reflect the prevalence of an anti-union ideology (for discussions, see Hogler and Shulman 1999, pages 928-29; Moore 1998; Moore and 
Newman 1985). This argument has made it more difficult for unions to claim that politicians are favoring management over labor if they pass RTW legislation because the politicians can respond that they are merely representing the wishes of their constituents. Our use of controls for labor relations, social capital, and political ideology in a union density equation allows us to assess the impact of RTW laws net of the effects of state differences in the ideologies and cultures that can affect unionization.

\section{FIGURE 1}

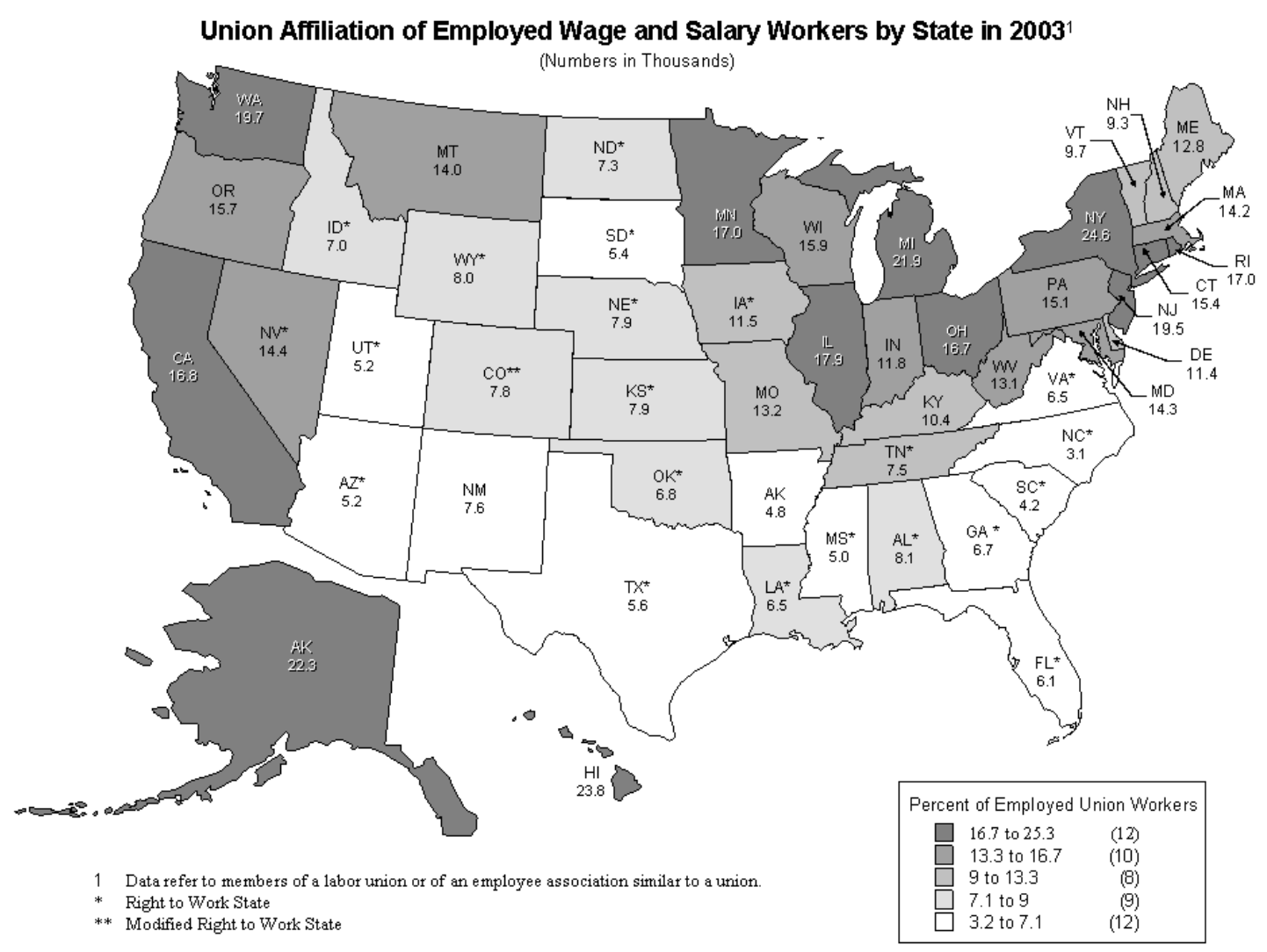

\subsection{Employer Opposition to Unions}

Many scholars have argued that union decline is in part attributable to the increasing opposition of employers to union organizing efforts (Freeman and Medoff 1984; Weiler 1992; Bronfenbrenner and Juravich 1998; Rose and Chaison 2001; Kleiner 2001). According to Paul Weiler (1983), unfair labor practice charges against employers rose from 4,472 in 1950 to 31,281 in 1980, and the National Labor Relations Board found more than a third of the charges to be meritorious. During that period, the average annual number of certification elections rose only slightly. The obvious point, Weiler 
concluded, was that "the explosion of employer unfair labor practices has in fact impeded employees in their attempts to bargain collectively" (1983, pages 1780-1781).

The "employer opposition thesis" continues to be an important factor in analyzing union density. Recent surveys find there is a strong desire for some form of representation among nonunion workers (Freeman and Rogers 1999), but unorganized workers may perceive that any attempt to unionize will lead to managerial intimidation and retaliation. Even if unions increase productivity, employers may justifiably believe that they nonetheless raise unit labor costs and lower profits (Lazear 1998, pages 521-523; Freeman and Medoff 1984). As a result, most employees believe that management will either make an "all-out effort" to defeat an organizing drive or at the least will try to dissuade workers from voting for the union (Kleiner 2001). Because sanctions under the National Labor Relations Act are insufficient to deter unlawful action, managers will engage in the "high-payoff strategy" of resistance. Kleiner (2001, pages 535-536) shows that the intensity of managerial opposition accounts for about 40 percent of the decline in private sector union density.

For these reasons, the degree of employer hostility to unions is a key explanatory variable in union penetration. Following Freeman and Medoff (1984), we use unfair labor practice charges, relative to the number of representation petitions, as an indicator of the intensity of employer opposition to unions. The index is constructed from 19801990 data in NLRB annual reports as presented in Hogler and Shulman (1999). This period encompassed the major postwar attrition of union membership (Masters 1997, page 44), and it thus represents a decade of aggressive reaction to labor's collective bargaining activities. The index assumes that employer opposition arises primarily in response to organizing threats. As Table 1 shows, the opposition index reveals substantial differences among states, ranging from a high of 7.65 unfair labor practice charges for every representation petition filed in West Virginia to a low of 1.78 charges per petition in North Dakota. The opposition index should be negatively correlated with union density.

\subsection{Social Capital}

The impact of RTW laws on union density must be measured net of the other factors that influence workers' decisions to join unions, including their attitudes toward union organizing efforts. These attitudes are both social and political. We use the concept of "social capital" to capture the former. According to Bowles and Gintis, "social capital generally refers to trust, concern for one's associates, a willingness to live by the norms of one's community and to punish those who do not" (2002, page F419). James Coleman (1988), the sociologist who originated the concept, emphasized individuals' participation in social networks. Putnam (2000) describes social capital in terms of the collective value of these networks and the incentives they provide for reciprocity. Although the term has been used in different ways in different contexts (Adler and Kwon 2002), it reflects the investment in social bonds that is needed to achieve both individual and communal goals. 
Table 1

State Ratio of Unfair Labor Practice Charges to Election Petitions, 1980-90

\begin{tabular}{|c|c|c|c|}
\hline State & ULP & Election Petitions & Ratio \\
\hline West Virginia & 4,400 & 575 & 7.65 \\
\hline Indiana & 11,941 & 1,829 & 6.51 \\
\hline North Carolina & 3,817 & 593 & 6.44 \\
\hline Colorado & 4,587 & 748 & 6.13 \\
\hline Texas & 8,944 & 1,531 & 5.84 \\
\hline Nevada & 2,951 & 505 & 5.84 \\
\hline Tennessee & 6,396 & 1,148 & 5.57 \\
\hline Kentucky & 5,132 & 956 & 5.42 \\
\hline Georgia & 5,784 & 1,094 & 5.29 \\
\hline Oklahoma & 2,306 & 442 & 5.22 \\
\hline South Carolina & 1,421 & 278 & 5.11 \\
\hline Mississippi & 1,850 & 364 & 5.08 \\
\hline Louisiana & 2,630 & 519 & 5.07 \\
\hline Connecticut & 5,769 & 1,044 & 4.95 \\
\hline Ohio & 17,830 & 3,843 & 4.64 \\
\hline Virginia & 4,123 & 893 & 4.62 \\
\hline Wyoming & 398 & 91 & 4.37 \\
\hline Arizona & 3,291 & 755 & 4.36 \\
\hline Nebraska & 1,151 & 268 & 4.29 \\
\hline Maryland & 4,850 & 1,152 & 4.21 \\
\hline Massachusetts & 8,454 & 2,013 & 4.20 \\
\hline Rhode Island & 1,105 & 263 & 4.20 \\
\hline Missouri & 9,461 & 2,276 & 4.16 \\
\hline Michigan & 15,732 & 3,852 & 4.08 \\
\hline California & 34,461 & 8,492 & 4.06 \\
\hline Florida & 6,970 & 1,722 & 4.05 \\
\hline Illinois & 16,551 & 4,097 & 4.04 \\
\hline Pennsylvania & 17,072 & 4,281 & 3.99 \\
\hline Wisconsin & 6,375 & 1,599 & 3.99 \\
\hline Vermont & 450 & 114 & 3.95 \\
\hline Arkansas & 1,600 & 409 & 3.91 \\
\hline New Mexico & 1,099 & 288 & 3.82 \\
\hline Kansas & 1,809 & 476 & 3.80 \\
\hline Washington & 6,789 & 1,801 & 3.77 \\
\hline Alabama & 3,176 & 867 & 3.66 \\
\hline New Hampshire & 589 & 165 & 3.57 \\
\hline Maine & 956 & 274 & 3.49 \\
\hline Alaska & 1,152 & 342 & 3.37 \\
\hline New York & 23,446 & 7,232 & 3.24 \\
\hline Delaware & 603 & 186 & 3.24 \\
\hline New Jersey & 9,910 & 3,218 & 3.08 \\
\hline Oregon & 2,899 & 1,000 & 2.90 \\
\hline Iowa & 2,097 & 750 & 2.80 \\
\hline Hawaii & 1,395 & 531 & 2.63 \\
\hline Idaho & 767 & 297 & 2.58 \\
\hline Montana & 1,100 & 437 & 2.52 \\
\hline Utah & 766 & 308 & 2.49 \\
\hline South Dakota & 228 & 102 & 2.24 \\
\hline Minnesota & 3,157 & 1,471 & 2.15 \\
\hline North Dakota & 271 & 152 & 1.78 \\
\hline
\end{tabular}


Unionism is affected by its social context, but the way in which it is affected is not simple or obvious. Antipathy to social networks and obligations (weak social capital) will reduce the propensity to join a union, but civic activism and well-developed networks (strong social capital) can do the same if they diminish the perceived need for a union or function as alternatives to it. Weak social capital can give workers an incentive to join a union in order to satisfy their social needs, but strong social capital can also increase the incentive to join a union if it raises the perceived return from doing so.

In practice the impact of social capital on unionism will depend upon the balance of these conflicting forces. Putnam (2000) believes that unions provide an institutional means of forming social capital, and that social capital facilitates the formation of unions. He views unionism and social capital as complements. But they could also be substitutes. Consider, for example, the interpretation of social capital as trust. Trust among workers can increase the appeal of union organizers (Levi 2000), but trust between workers and managers might lower workers' demand for unions. Other components of social capital could also reduce the appeal of unions. Attending town meetings, volunteering in the local school, and related kinds of participation can act as alternatives to unions as a means of creating social networks and achieving collective goals. Under those circumstances, high levels of social capital could dampen preferences for workplace collective action.

Thus, the overall effects of social capital on union density could be positive or negative. To our knowledge, a social capital variable has not been included in previous studies of union density, although beliefs in the efficacy of group as opposed to individual action could be an important correlate of union density. In this study, we rely on Putnam's (2000) influential study of social capital in the U.S. Putnam constructs a measure of social capital across the contiguous states based on responses to a variety of surveys. Fourteen indicators are used to determine a state's level of social capital, including such survey items as "I spend a lot of time visiting friends," "most people can be trusted," "most people are honest." Other components of the social capital index include attendance at public meetings, membership in social organizations, volunteer activities, and related social events. By combining these indicators into a social capital index, Putnam ranks the 48 states from a positive score of 1.71 (North Dakota) to -1.43 (Nevada). We utilize both the social capital index and its components in order to gain insight into the ways in which social context can affect union density. We cannot predict the sign on the social capital coefficient since it will depend upon the balance of positive and negative influences on union density.

\subsection{Political Ideology}

The social capital index does not include any direct measures of attitudes about unions or politics. Consequently, we include a separate variable to capture the impact of political ideology on union density. Liberal and conservative political beliefs are often taken to respectively represent positive and negative beliefs about unions and compulsory financial support (Gall 1996). Palley (2001) uses the share of Republican votes to total 
votes for president in the election of 1996 as a proxy for anti-union attitudes in a crosssectional equation on states. He finds that this variable has a significant, negative impact on union density. Lipset and Katchanovski (2001) found that social democratic values are positively correlated with union density. Political ideas clearly are an important dimension of workers' propensities for unionization and should be taken into account in assessing membership trends. Consistent with this line of research, we use the percent of state voters who favored the Democrats in the 2000 presidential election as a measure of political ideology (Federal Election Commission 2000). We expect the coefficient of this variable to be positive.

\subsection{Labor Market and Worker Characteristics}

To construct a comprehensive model, we also included variables representing gross state product, income inequality, industrial structure, and educational attainment. The impact of the focus variables - employer opposition, political ideology, and social capital - must be determined net of the labor market and worker characteristics that can also affect union density. The method and results are discussed below.

\section{EMPIRICAL ANALYSIS}

\subsection{Econometric Model and Initial Results}

We first estimate the following equation:

$$
\mathrm{UNION}_{\mathrm{i}}=\alpha+\beta_{1} \mathrm{ULP}_{i}+\beta_{2} \mathrm{SOCK}_{i}+\beta_{3} \mathrm{RTW}_{i}+\beta_{4} \mathrm{DEMO}_{i}+\beta_{5} X_{i}+e_{i}
$$

where UNION is the percent of the state's labor force that belonged to a union in 2000, ULP is the unfair labor practices index developed by Hogler and Shulman (1999), SOCK is the social capital index measure constructed by Putnam (2000), RTW is a dummy variable valued at unity if the state has right-to-work laws and zero otherwise, and DEMO is the percent of voters who voted for the Democratic candidate in the last presidential election. A variety of controls for labor market and worker characteristics are also included, represented by the vector $X$. The units of analysis are the 48 contiguous states, $i$ (SOCK is not available for Hawaii and Alaska). Variable descriptions and data sources are presented in Table 2.

The correlation coefficients listed in Table 3 show an interesting set of relationships among the explanatory variables. DEMO shows no strong relationships to the other variables except RTW. The negative correlation between DEMO and RTW indicates that DEMO may be a proxy for political beliefs hostile to RTW legislation. SOCK is not correlated with DEMO, supporting the argument of Bowles and Gintis (2002) that social capital is not necessarily associated with either liberal or conservative political beliefs, but the negative correlation of SOCK with RTW and ULP does suggest that SOCK may be capturing social attitudes that are positively associated with unionism. These correlations support our contention that the inclusion of both SOCK and DEMO controls 
Table 2

Variable Descriptions and Data Sources

\begin{tabular}{|c|c|c|}
\hline Variable & Description & Data Source \\
\hline UNION & $\begin{array}{l}\text { Union membership as a percent of } \\
\text { state labor force, } 2003\end{array}$ & $\begin{array}{l}\text { Bureau of Labor Statistics. Data available online at } \\
\text { http://www.bls.gov/news.release/union2.t05.htm. }\end{array}$ \\
\hline RTW & $\begin{array}{l}\text { Dummy variable }=1 \text { if right-to- } \\
\text { work state, } 0 \text { otherwise, as of } 2004\end{array}$ & $\begin{array}{l}\text { Bureau of Labor Statistics. Data available online at } \\
\mathrm{http} / / \text { www.dol.gov/esa/programs/whd/state/righttowork } \\
\mathrm{htm}\end{array}$ \\
\hline ULP & $\begin{array}{l}\text { Employer opposition index, i.e., } \\
\text { ratio of unfair labor practice charges } \\
\text { to election petitions, 1980-1990 }\end{array}$ & 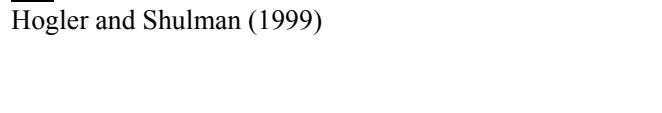 \\
\hline DEMO & $\begin{array}{l}\text { Percent of voters who voted for the } \\
\text { Democratic candidate for President } \\
\text { in } 2000\end{array}$ & $\begin{array}{l}\text { Federal Election Commission. Data available online at } \\
\mathrm{http} / / / \mathrm{www} \cdot \mathrm{fec} \cdot \text { gov/pubrec/ 2000presgeresults.htm }\end{array}$ \\
\hline SOCK & Social capital index & $\begin{array}{l}\text { Putnam (2000). Data available online at } \\
\text { http://www.bowlingalone.com/data.php3 }\end{array}$ \\
\hline MEETING & $\begin{array}{l}\text { Attendance at town or school board } \\
\text { meetings (component of SOCK) }\end{array}$ & $\begin{array}{l}\text { Putnam (2000). Data available online at } \\
\text { http://www.bowlingalone.com/data.php3 }\end{array}$ \\
\hline VOTE & $\begin{array}{l}\text { Percent of the electorate that voted } \\
\text { in the } 1988 \text { and } 1992 \text { presidential } \\
\text { elections (component of SOCK) }\end{array}$ & $\begin{array}{l}\text { Putnam (2000). Data available online at } \\
\text { http://www.bowlingalone.com/data.php3 }\end{array}$ \\
\hline COL & $\begin{array}{l}\text { Percent of state population } 25 \text { years } \\
\text { old or older with a bachelor's degree }\end{array}$ & $\begin{array}{l}2000 \text { Census. Data available online at http://www. } \\
\text { census.gov/prod/2003pubs/c2kbr-24.pdf }\end{array}$ \\
\hline PERCAPY & Per capita income, 2000 & $\begin{array}{l}\text { Bureau of Economic Analysis. Data available online at } \\
\mathrm{http} / / / \mathrm{ww} \text {.bea.doc.gov/bea/regional/ statelocal.htm }\end{array}$ \\
\hline GSP98 & Gross state product, 1998 & $\begin{array}{l}\text { Bureau of Economic Analysis. Data available online at } \\
\mathrm{http} / / \mathrm{ww} w . \text { bea.doc.gov/bea/regional/gsp/ action.cfm }\end{array}$ \\
\hline GSP90 & Gross state product, 1990 & $\begin{array}{l}\text { Bureau of Economic Analysis. Data available online at } \\
\mathrm{http} / / \mathrm{ww} w . \text { bea.doc.gov/bea/regional } / \mathrm{gsp} / \mathrm{action} . \mathrm{cfm}\end{array}$ \\
\hline GROWTH & $\begin{array}{l}\text { Percent change in state employment, } \\
1990-1999\end{array}$ & $\begin{array}{l}\text { Bureau of Labor Statistics. Data available online at } \\
\text { http://www.bls.gov/sae/home.htm }\end{array}$ \\
\hline GOV & $\begin{array}{l}\text { Percentage of employed persons in } \\
\text { government sector, } 2000\end{array}$ & $\begin{array}{l}\text { Bureau of Economic Analysis. Data available online at } \\
\mathrm{http} / / / \mathrm{ww} w . \text { bea.gov/bea/regional/ statelocal.htm }\end{array}$ \\
\hline SERV & $\begin{array}{l}\text { Percentage of employed persons in } \\
\text { service sector, } 2000\end{array}$ & $\begin{array}{l}\text { Bureau of Economic Analysis. Data available online at } \\
\text { http://www.bea.gov/bea/regional/ statelocal.htm }\end{array}$ \\
\hline MFG & $\begin{array}{l}\text { Percentage of employed persons in } \\
\text { manufacturing sector, } 2000\end{array}$ & $\begin{array}{l}\text { Bureau of Economic Analysis. Data available online at } \\
\text { http://www.bea.gov/bea/ regional/statelocal.htm }\end{array}$ \\
\hline INEQUAL & $\begin{array}{l}\text { Gini measure of state income } \\
\text { inequality, } 2000 .\end{array}$ & Eckert and Garner (2003). \\
\hline RURAL & $\begin{array}{l}\text { Percent of state population living in } \\
\text { rural areas }\end{array}$ & $\begin{array}{l}2000 \text { Census. Data available online at http://www. } \\
\text { census.gov/Press-Release/www/2001/sumfile1. html }\end{array}$ \\
\hline PLAINS & $\begin{array}{l}\text { Dummy variable }=1 \text { if state is in } \\
\text { BEA's "Plains" region, i.e., IA, KS, } \\
\text { MN, MO, NE, ND, SD }\end{array}$ & $\begin{array}{l}\text { Bureau of Economic Analysis. Data available online at } \\
\mathrm{http} / / \mathrm{ww} w \cdot \text { bea.gov/bea/ regional/docs/regions.asp }\end{array}$ \\
\hline SEAST & $\begin{array}{l}\text { Dummy variable }=1 \text { if state is in } \\
\text { BEA's "Southeast" region, i.e., AL, } \\
\text { AR, FL, GA, KY, LA, MS, NC, SC, } \\
\text { TN, VA, WV }\end{array}$ & $\begin{array}{l}\text { Bureau of Economic Analysis. Data available online at } \\
\mathrm{http} / / / \mathrm{ww} w \cdot \text { bea.gov/bea/ regional/docs/regions.asp }\end{array}$ \\
\hline URBAN40 & $\begin{array}{l}\text { Percentage of state population } \\
\text { residing in urban areas, } 1940\end{array}$ & $\begin{array}{l}\text { Census Bureau. Data available online at } \\
\text { http://www.census.gov/population/censusdata/urpop0090. } \\
\text { txt }\end{array}$ \\
\hline
\end{tabular}


Table 3

Correlation Coefficients

\begin{tabular}{ccccc}
\hline & SOCK & RTW & ULP & DEMO \\
\hline SOCK & 1.000 & -0.428 & -0.605 & 0.003 \\
RTW & -0.428 & 1.000 & 0.139 & -0.521 \\
ULP & -0.605 & 0.139 & 1.000 & -0.127 \\
DEMO & 0.003 & -0.521 & -0.127 & 1.000 \\
\hline Note: See Table 2 for variable definitions and data sources. & \\
\hline
\end{tabular}

for the social and political beliefs that affect union membership; consequently, the effect of RTW on union density represents a true legislative effect.

At the same time, it is noteworthy that ULP shows no correlation with DEMO or RTW. Unfair labor practices do not seem to correspond to particular political beliefs or union legislation even if they are correlated with social attitudes and actions. The strength of these correlations and their correspondence with our assumptions increases our confidence that the variables we are using are capturing meaningful social, ideological, and political forces that can affect union density.

Like all union density equations, the one described above is subject to two potential econometric pitfalls. The first is omitted variable bias. If anti-union attitudes both depress union density and facilitate the passage of RTW laws, and if RTW laws have no independent influence on union density, then omission of variables representing attitudes toward unions will result in a spurious correlation between RTW laws and union density. The solution is to find variables that proxy attitudes toward unions. Our model represents a step forward in this literature because we utilize novel and intuitively plausible proxies for attitudes toward unions. If RTW laws have no independent influence on union density, then the RTW dummy will lose its significance once variables that represent underlying attitudes toward unions are included in a union density equation. Some studies have yielded this result (summarized in Moore and Newman 1985); however, Moore (1998, page 451) notes that it may be due to multicollinearity between the taste variables and the RTW dummy. Since our results (described below) show high significance levels for both the taste variables and for the RTW variable, multicollinearity does not appear to be a problem in our specification. Since we also explain a very high fraction of the stateto-state variation in union density, we believe that we have substantially solved the problem of omitted variable bias.

The second possible problem is simultaneity between RTW laws and union density. Since unions lobby against RTW laws, causality could go from the dependent variable to one of the independent variables, biasing the results. The usual solution to this problem is to utilize a simultaneous equations approach. Studies that have done so have yielded mixed results (Moore and Newman 1985). 
Hausman specification tests and two-stage least squares (TSLS) techniques can respectively evaluate and overcome potential simultaneity bias. A key issue is finding appropriate instrumental variables. A wide variety of instruments were incorporated, most notably the percentage of a state's population residing in urban areas in 1940 (see Table 4 for list of instruments). This variable predates both the dependent union density variable and state RTW legislation laws and is thus predetermined relative to both. It is also highly correlated (.74) with union density, an unsurprising finding given the predominant role of unionized urban manufacturing establishments during that period of labor organization. Other largely predetermined instruments include gross state product for 1990 and state employment growth over the 1990s.

In the present case, some specifications of the Hausman test find simultaneity between unionization and RTW legislation, but the findings are inconsistent and inconclusive. Therefore, we still applied a TSLS procedure to account for any potential simultaneity. A representative set of final results is presented in Table 4. Alternative specifications, such as including a wider variety of instruments, yielded virtually identical results.

Key OLS results proved to be robust when they converged with TSLS estimates using a variety of instruments. In particular, the RTW finding remains steady and significant, indicating that RTW effects are not spurious artifacts of the likely union lobbying against such legislation. The TSLS coefficient for RTW is roughly double that of the OLS results, suggesting that the latter is in fact a conservative measure of the crosssectional impact of RTW legislation on state union density. The TSLS findings also show that per capita incomes are not significant determinants of state union density, with the TSLS procedure incorporating the possibility that unionization itself may shape per capita incomes. While superficially surprising, the finding is consistent with other recent

Table 4

TSLS Regression Results Dependent Variable: UNION

\begin{tabular}{ccc}
\hline Variable & Coefficient & Standard Error \\
\hline Constant & $45.28^{1}$ & 16.12 \\
RTW & $-14.97^{1}$ & 3.52 \\
ULP & $-1.85^{2}$ & 0.72 \\
MEET & $-51.97^{2}$ & 20.59 \\
DEMO & -0.26 & 0.23 \\
PERCAPY & 0.0001 & 0.0002 \\
\hline Adjusted R-squared 0.46 & \\
1 Significant at the 1 percent level & \\
2 Significant at the 5 percent level & \\
Instrument list: C, ULP, MEETING, DEMO, PERCAPY, URBAN40, GSP90, GROWTH. \\
See Table 2 for variable descriptions and data sources. \\
\hline
\end{tabular}


empirical studies of union density (e.g., Palley 2001) and reinforces the need to understand the underlying sources of varying union concentrations across states. Finally, SOCK was negative and significant when introduced alone in the TSLS specification, but its significance disappeared when one of its components, MEETING (attendance at town or school board meetings), was introduced as an explanatory variable. We use these TSLS findings to structure our final OLS inquiries regarding union density and social capital, as described below.

Complete OLS regression results are shown in Table 5; again, these findings were substantively identical to those from TSLS procedures using a range of instruments. The summary statistics show that the equation is robust. Our explanatory variables are unconventional but surprisingly revealing. RTW is significant within 1 percent, ULP is significant within 5 percent, and each has the expected signs. DEMO and the control variables are not significant, which may be due to multicollinearity among them. The equation explains nearly two-thirds of the state-to-state variance in union density. These results indicate that the variables we have utilized reflect most of the causes of interstate variations in union density.

The exception is SOCK. Its coefficient is negative, but it is difficult to interpret this result since its significance level is so low. It does not appear to be robust in a union density equation, perhaps because the social capital index is a composite of many different indicators of social attitudes and actions, or perhaps because its effects are being

Table 5

OLS Regression Results Dependent Variable: UNION

\begin{tabular}{ccc}
\hline Variable & Coefficient & Standard Error \\
\hline Constant & 12.80 & 15.03 \\
SOCK & -0.87 & 0.90 \\
ULP & $-1.13^{2}$ & 0.43 \\
RTW & $-6.96^{1}$ & 1.27 \\
DEMO & 0.07 & 0.11 \\
INEQUAL & -0.49 & 0.42 \\
COLLEGE & -0.20 & 0.12 \\
GSP98 & 0.004 & 0.003 \\
MFG & 13.66 & 25.89 \\
GOV & -3.72 & 22.75 \\
SERV & 34.18 & 31.55 \\
\hline Adjusted R-squared $\quad 0.65$ & & \\
Durbin-Watson & 2.04 & \\
F-statistic & 9.69 & \\
1 Significant at the 1 percent level & & \\
2 Significant at the 5 percent level & \\
See Table 2 for variable descriptions and data sources. & \\
\hline
\end{tabular}


transmitted through its negative correlations with RTW and ULP. Because SOCK is an unusual control to include in a union density equation, we explored this variable in greater econometric detail to get some insight into its determinants and effects.

\subsection{Extension of Analysis with the Social Capital Variable}

We argued above that SOCK could have either a positive or negative effect on UNION. To demonstrate the potential complexity of Putnam's social capital index as a determinant of union density, we ran the following cross-sectional equation with states (denoted by the subscript $i$ ) as units of observation:

$$
\mathrm{SOCK}_{i}=\alpha+\beta_{1} \mathrm{COL}_{i}+\beta_{2} \mathrm{ULP}+\beta_{3} \mathrm{INEQUAL}_{i}+\beta_{4} \mathrm{RURAL}_{i}+\beta_{5} \mathrm{PLAINS}_{i}+\beta_{6} \mathrm{SEAST}_{i}+e_{i}
$$

where SOCK is Putnam's social capital index, COL is the percent of the state's adult population with a college degree, ULP is the unfair labor practices index (shown in Table 3 to be highly correlated with SOCK), INEQUAL is income inequality within each state as measured by the Gini index, RURAL is the percentage of state population living in rural areas, and PLAINS and SEAST are regional dummies. (Other regional dummies were insignificant and were dropped.) These variables represent the personal, economic, and regional factors that can affect the acquisition of social capital. As far as we know, the use of a Gini index for states is new, though results are substantially the same when we substitute the $80-20$ ratio as a measure of income inequality. See Table 2 for variable definitions and data sources.

Results are shown in Table 6. Despite the large number of components that go into SOCK, the equation explains nearly four-fifths of its variation. This is quite high for a cross-sectional equation, especially given the large number of components in SOCK and the small number of independent variables. Social capital rises with education and falls with inequality. As expected, college education has a positive effect, perhaps because it improves social and communication skills and encourages political participation and civic activism. It is also not surprising that inequality reduces social capital, perhaps because it inhibits the perception of a common social identity and increases social stratification. Social capital falls as complaints of unfair labor practices rise, reflecting the negative impact of a hostile labor relations environment on the formation of social networks. Social capital is higher in rural states, indicating that rural regions have a greater sense of social trust and communal solidarity than more urbanized regions. Interestingly, plains states have higher social capital over and above their rural character, while southeastern states have lower social capital. Both could be evidence of historical factors, particularly in the heritage of mutual support in the plains states during their development.

These results make sense and increase our confidence in SOCK as a measure of social capital. They also indicate the potential complexities of the impact of social capital on union density. Unions are negatively correlated with both college education and inequality, but SOCK rises with COL and falls with INEQUAL. Union density is lower in the plains states where social capital is higher and lower in the southeastern 
Table 6

OLS Regression Results

Dependent Variable: SOCK

\begin{tabular}{|c|c|c|}
\hline Variable & Coefficient & Standard Error \\
\hline CONSTANT & 2.47 & 1.76 \\
\hline ULP & $-0.16^{1}$ & 0.05 \\
\hline $\mathrm{COL}$ & $0.04^{1}$ & 0.01 \\
\hline INEQUAL & $-7.63^{2}$ & 3.73 \\
\hline RURAL & $2.14^{1}$ & 0.47 \\
\hline PLAINS & $0.48^{1}$ & 0.17 \\
\hline SEAST & $-0.75^{1}$ & 0.18 \\
\hline \\
\hline \multicolumn{3}{|c|}{ Durbin-Watson $\quad 1.90$} \\
\hline \multirow{2}{*}{\multicolumn{3}{|c|}{$\begin{array}{ll}\text { F-statistic } & 30.15 \\
{ }^{1} \text { Significant at the } 1 \text { nercent level }\end{array}$}} \\
\hline & & \\
\hline \multicolumn{3}{|c|}{${ }^{2}$ Significant at the 5 percent level } \\
\hline See Table 2 for variab & data sources. & \\
\hline
\end{tabular}

states where social capital is lower. Taken together these mixed correlations mean that the impact of SOCK on union density could be either positive or negative depending upon the balance of these opposing forces.

These potentially conflicting effects of SOCK on UNION can explain its low significance level in the union density equation. Nonetheless, SOCK does reflect social practices and beliefs that should affect UNION. To gain more insight into the role of social capital as a determinant of union density, we ran additional regressions using the components of SOCK in place of the index itself, adding in each component of SOCK one by one in separate equations, leaving in the other focus variables (Hendry, Pagan, and Sargan 1982). Only MEETING was significant.

The final equation thus includes the MEETING component of SOCK as well as RTW and ULP, following the TSLS results in Table 4. The other control variables used initially are excluded because of their low significance levels (see Table 5). This leaves us with a very simple equation, though the findings are substantially the same when all the control variables are included. Results are shown in Table 7. Each of the explanatory variables is significant within the 5 percent level. The equation explains three-quarters of the state-to-state variation in union density. This is very high for a cross-sectional equation, particularly one with a small number of explanatory variables. The coefficients for all of the primary explanatory variables, most notably RTW, remain virtually identical in the new equation, further underlining the robustness of the results.

This final regression allows us to focus on MEETING, the remaining SOCK component of note. The negative coefficient on MEETING shows that civic activism is negatively correlated with union membership and may function as a substitute for it. The 
Table 7

OLS Regression Results

Dependent Variable: UNION

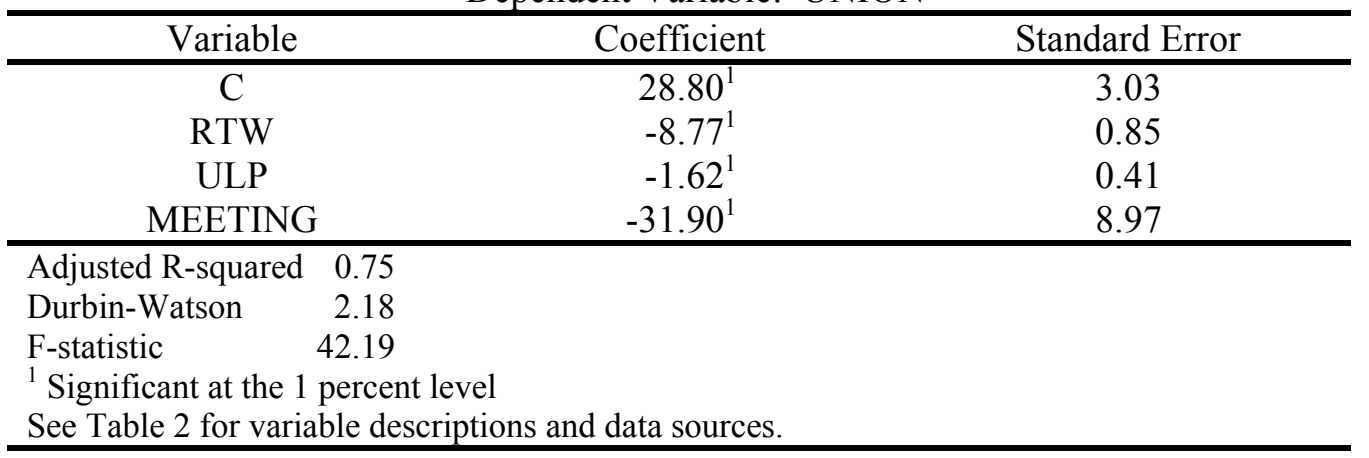

other focus variables retain their signs and significance. Higher levels of unfair labor practices are associated with lower union density, while RTW states also feature lower rates of unionization. These results are important because each controls for the other. Even holding employer opposition, political ideology, and civic activism constant, RTW laws lead to lower union density. States with such legislation have lower union densities than their otherwise identical counterparts by 8.8 percentage points. Similarly, greater numbers of unfair labor practices tend also to reduce unionization, even when controlling for RTW status and the ideological and social variables. States with demonstrated hostility towards unions have significantly lower unionization rates. These findings demonstrate that RTW laws exert an independent, negative influence on union density after controlling for the social and labor relations environments that can affect both.

\section{CONCLUSIONS}

Our central finding is that RTW laws reduce the ability of unions to organize workers and to develop workplace institutions conducive to collective bargaining. Even after taking account of the social and labor relations contexts within which unions function, RTW laws significantly reduce union density. Our findings show that RTW laws exert an independent and strongly negative effect on union density, with a magnitude of 8.8 percentage points, ceteris paribus. This is a true legislative impact, not an artifact of underlying anti-union attitudes.

The results of the control variables are also of considerable interest, especially since they are net of each other's effects. States with a relatively greater number of unfair labor practices - indicating greater employer opposition to worker organization - have systematically lowered unionization rates. Further, unions appear to be effective substitutes for low levels of civic participation because they give workers an institution to bridge gaps in trust. This study's unique cross-sectional combination of right-to-work, unfair labor practices, and social capital explains over three-fourths of the state-to-state variation in union density. 
Social capital itself is negatively related to income inequality and unfair labor practices. This finding illustrates the destructive effects of economic polarization and hostile labor relations on the social fabric. Putnam (2000) emphasized the roles of generational change, television, and suburbanization in the decline of social capital; but our results indicate that income inequality and workplace conflicts are also to blame. The loss of social cohesion documented by Putnam is in part a product of these labor market and workplace trends.

Our findings show that the debate about RTW laws is meaningful. The proponents and opponents of RTW laws disagree about an issue that has concrete consequences for the labor movement and for labor markets. The debate would be pointless if RTW laws had no independent impact on union density, but our results show that this is not the case. The question is not whether RTW laws have real effects, but how to assess them.

\section{REFERENCES}

Adler, P. and S.W. Kwon, 2002. "Social Capital: Prospects for a New Concept," Academy of Management Review 27 (1), 17-40.

Bowles, S. and H. Gintis, 2002. "Social Capital and Community Governance," The Economic Journal 112, F419-F436.

Bronfenbrenner, K. \& Juravich, T. 1998. "It Takes More than House Calls: Organizing to Win with a Comprehensive Union-Building Strategy." In K. Bronfenbrenner, S. Friedman, R. W. Hurd, R. A. Oswal, and R. L. Seeber, Organizing to Win: New Research on Union Strategies. Ithaca, NY: ILR Press, pp. 19-36.

Bureau of Labor Statistics, 2003. Union Members Summary. http://stats.bls.gov/ newsrels.htm.

Coleman, J., 1988. "Social Capital in the Creation of Human Capital," American Journal of Sociology 94 (Supplement), S95-S120.

Dinlersoz, E.M. and R. Hernández-Murillo, 2002. "Did 'Right-to-Work' Work for Idaho?" Federal Reserve Bank of St. Louis 84, 29-43.

Eckert, J. and E. Garner, 2003. "Income Inequality in Colorado," research report prepared for Cooperative Extension, Colorado State University (January). Internet release available at http://www.ext.colostate.edu/staffres/cis/xcm227-full.pdf.

Federal Election Commission, Federal Elections 2000. Available at http://www.fec.gov/pubrec /fe2000.tcontents.htm

Freeman, R. and J. Medoff, 1984. What Do Unions Do? New York: Basic Books. Freeman, R. and J. Rogers, 1999. What Workers Want. Ithaca: ILR Press.

Gall, G.J., 1996. "Union Security Rights at the Polls: A Call for Modeling Right-toWork Voting," Employee Responsibilities and Rights Journal 9, 41-56.

Greer, S. and C.W. Baird, 2003. "Reply to Hogler and LaJeunesse's 'Oklahoma's Right to Work Initiative: Labor Policy and Political Ideology,'” Labor Law Journal 54(2), 89-98. 
Hendry, D.F, A.R. Pagan, and J.D. Sargan, 1982. "Dynamic Specification,” in Z. Griliches and M.D. Intriligator (eds.), Handbook of Econometrics. Amsterdam: North-Holland.

Hogler, R. and R. LaJeunesse, 2002. "Oklahoma's Right to Work Initiative: Labor Policy and Political Ideology," Labor Law Journal 53 (3), 109-121. , 2003. "Labor Policy and Civic Values: The Curious Contradictions of Right to Work," Labor Law Journal 54 (3), 214-224.

Hogler, R. and S. Shulman, 1999. "The Law, Economics, and Politics of Right-to-Work: Colorado's Labor Peace Act and its Implications for Public Policy," University of Colorado Law Review 70(3), 871-952.

Hogler, R. and S. Shulman, and S. Weiler, 2003. "Right-to-Work Laws and Business Environments: An Analysis of State Labor Policy," Forthcoming in the Journal of Managerial Issues.

Holmes, T.J., 1998. "The Effect of State Policies on the Location of Manufacturing: Evidence from State Borders," Journal of Political Economy 106 (4), 667-705.

Kleiner, M., 2001. "Intensity of Management Resistance: Understanding the Decline of Unionization in the Private Sector," Journal of Labor Research 22 (3), 519-540.

Lazear, E.P., 1998. Personnel Economics for Managers. New York: John Wiley \& Sons.

Levi, M., 2000 "When Good Defenses Make Good Neighbors: A Transaction Cost Approach to Trust, the Absence of Trust and Distrust," in C. Menard (ed.), Institutions, Contracts and Organizations: Perspectives from New Institutional Economics. Cheltenham, UK: Edward Elgar, 158-171.

Lipset, S.M. and I. Katchanovski, 2001. "The Future of Private Sector Unions in the U.S.," Journal of Labor Research 22 (2), 229-44.

Masters, M. F., 1997. Unions at the Crossroads: Strategic Membership, Financial, and Political Perspectives. Quorum: Westport CT.

Moore, W.J., 1998. "The Determinants and Effects of Right-to-Work Laws: A Review of the Literature," Journal of Labor Research 19, 445-469.

Moore, W.J and R.J. Newman, 1985. "The Effects of Right to Work Laws: A Review of the Literature," Industrial and Labor Relations Review 38, 571-603.

Palley, T.I., 2001. "Right-to-Work (for Less): An Empirical Examination of the Impact of Right-to-Work Legislation on State Economic Outcomes," unpublished manuscript, Public Policy Department, AFL-CIO.

Putnam, R.D., 2000. Bowling Alone: The Collapse and Revival of American Community. NY: Simon \& Schuster.

Rose, J. and G. Chaison, 2001. "Unionism in Canada and the United States in the 21st Century: The Prospects for Revival," Relations Industrielles 56(1), 34-65.

Weiler, P., 1983. "Promises to Keep: Securing Workers' Rights to Self-Organization Under the NLRA," Harvard Law Review 96, 1769-1827. , 1992. "Hard Times for Unions: Challenging Times for Scholars," University of Chicago Law Review 58, 1015-32. 